\title{
Analisa Kualitas Perangkat Lunak Sistem Informasi Akademik Menggunakan McCall
}

\author{
Anita Hidayati, Elsa Oktariza, Fatimah Rosmaningsih, Suci Ana Lathifah \\ Program Studi Teknik Informatika Jurusan Teknik Informatika dan Komputer \\ Politeknik Negeri Jakarta \\ anita.hidayati@tik.pnj.ac.id, oktariza43@gmail.com,rosmaningsihfatimah@gmail.com, sucianalathifah@yahoo.com
}

Diterima: 5 Mei 2017. Disetujui 17 Mei 2017. Dipublikasikan Mei 2017

\begin{abstract}
Abstrak - Saat ini perangkat lunak sudah menjadi kebutuhan primer di setiap perguruan tinggi. Pengujian perangkat lunak merupakan satu hal yang penting dalam menentukan kualitas perangkat lunak. Penelitian ini dilakukan untuk mengetahui proses pengembangan fungsi perangkat lunak dan menguji kualitas perangkat lunak Sistem Informasi Akademik (SIAK) di Politeknik Negeri Jakarta (PNJ). Pengujian ini menggunakan kerangka kerja McCall pada lingkup product operation dimana hal yang diuji adalah faktor correctness, reliability, efficiency, integrity, dan usability. Metode yang digunakan adalah dengan menyebarkan kuesioner kepada mahasiswa PNJ yang berisi faktor kualitas perangkat lunak yang akan digunakan. Berdasarkan hasil kuesioner yang diperoleh dari tanggapan mahasiswa terhadap SIAK PNJ, masih terdapat beberapa kekurangan setelah dilakukan pengujian meliputi faktor kualitas dari sisi correctnes, efficiency, dan integrity. Sedangkan dari faktor usability dan reliability dapat dinyatakan bahwa SIAK PNJ telah memenuhi faktor kualitas perangkat lunak serta kebutuhan mahasiswa PNJ.
\end{abstract}

Kata Kunci: SQA, McCall, faktor kualitas perangkat lunak, SIAK.

\section{PENDAHULUAN}

Aspek kualitas perangkat lunak merupakan salah satu hal yang penting dalam pengembangan suatu software [1]. Suatu perangkat lunak bukan hanya dilihat dari hasil produknya tapi juga dilihat dari sisi tahap pengembangan perangkat lunak itu sendiri [2]. Dalam pengembangan suatu software dibutuhkan penjaminan kualitas dalam setiap tahap daur hidup perangkat lunak. Terdapat beberapa karakteristik yang umum mengenai penilaian kualitas perangkat lunak, baik secara kualitatif ataupun secara kuantitatif [3]. Suatu proyek perangkat lunak harus memiliki performa yang baik, seperti pada tahap perencanaan sistem, perancangan sistem, kehandalan, software reuse, dan perawatan perangkat lunak.

Politeknik Negeri Jakarta (PNJ) merupakan salah satu institusi pendidikan yang telah menggunakan perangkat lunak sebagai alat bantu dalam memberikan informasi-informasi yang diperlukan oleh mahasiswa khususnya bidang akademik. PNJ sudah mengimplementasikan Sistem Informasi Akademik (SIAK) untuk melayani kegiatan akademik civitas akademika. Sistem ini digunakan oleh 3 kelompok pengguna, yaitu sebagai mahasiswa, dosen, dan staf akademik sebagai administrator sistem. Permasalahan yang terjadi adalah SIAK sebagai perangkat lunak aplikasi sudah lama diimplementasikan namun belum pernah diuji kehandalannya. Pengujian hanya dilakukan untuk kelompok pengguna pada level mahasiswa. Oleh karena itu, penelitian ini bertujuan untuk melakukan analisis terhadap SIAK di PNJ menggunakan atribut McCall sehingga mendapatkan gambaran tentang kondisi penjaminan kualitas perangkat lunak pada Politeknik Negeri Jakarta.

\section{MODEL FAKTOR KUALITAS}

Dalam jurnal "Analisis Kualitas Perangkat Lunak Terhadap Sistem Informasi UNIKOM" [4] pada tahun 2013, menurut McCall model klasik dari faktor kualitas perangkat lunak terdiri dari 11 faktor. Model yang lain terdiri dari 12 sampai 15 faktor yang dikemukakan oleh Deutsch dan Willis dan oleh Evans dan Marciniak. Perbedaan alternative model tidak jauh beda dengan model McCall. Perbedaan ini dapat terlihat pada sudut pandang pencipta masing-masing model. Model faktor McCall mengklasifikasikan semua kebutuhan perangkat lunak ke dalam 11 faktor kualitas. Kesebelas faktor tersebut dibagi menjadi tiga kategori menjadi faktor operasi produk, faktor revisi 
produk, dan faktor transisi produk. Model kualitas McCall pada faktor operasi produk [5] berisi:

\section{- Correctness}

Tingkat pemenuhan program terhadap kebutuhan yang dispesifikasikan dan memenuhi tujuan/misi pelanggan sudah benar Sebuah perangkat lunak dapat dikatakan benar jika dapat menghasilkan keluaran yang benar untuk setiap kemungkinan masukan oleh pengguna, melakukan proses yang seharusnya (tidak kurang dan tidak berlebihan), dan secara formal harus bisa dibuktikan secara matematis.

- Reliability

Beberapa fungsi mungkin tidak bekerja dalam eksekusi pada perangkat lunak, sehingga dianggap tidak tepat. Namun, perangkat lunak masih bisa diterima oleh pelanggan karena eksekusi yang menyebabkan sistem gagal mungkin tidak sering terjadi saat sistem dikerahkan. Selain itu, mungkin sesekali pelanggan akan menerima kegagalan perangkat lunak tersebut. Pelanggan mungkin masih menganggap sistem yang salah dapat diandalkan jika tingkat kegagalannya sangat kecil dan tidak mempengaruhi tujuan/misi mereka. Kesesuaian adalah persepsi pelanggan, dan perangkat lunak yang salah masih dapat dianggap sesuai

- Efficiency

Ada dua pengertian tentang efisiensi sebuah perangkat lunak. McCall mengartikannya sebagai penggunaan sumber daya seperti waktu pemrosesan processor (eksekusi), pemakaian media penyimpanan (memori, space, bandwidth). Sedangkan menurut ISO 9126, efisiensi berkaitan dengan hubungan antara kinerja perangkat lunak dan jumlah sumber daya yang digunakan

- Usability

Faktor ini melihat dari kemudahan perangkat lunak untuk digunakan dan dipelajari [6]. Usability mempunyai unsur akademis seperti psikologis, ergonomi, dan human factors.

- Maintainability

Maintainability adalah kemudahan dari perangkat lunak untuk dipelihara, seperti memperbaiki kerusakan, menemukan kebutuhan baru, membuat pemeliharaan selanjutnya lebih mudah, mengatasi lingkungan yang berubah. Sebuah perangkat lunak dikatakan dapat dipelihara jika koreksi dari minor bugs memerlukan usaha yang kecil.

- Flexibility
Flexibility adalah kemudahan dalam membuat perubahan yang dibutuhkan akibat perubahan lingkungan (McCall) serta melakukan modifikasi kode untuk memfasilitasi perubahan yang telah ditentukan.

- Testability

Merupakan kemampuan perangkat lunak untuk diuji. Selain itu testability adalah derajat yang dimiliki sebuah sistem untuk memfasilitasi kriteria pengujian dan performansi dari pengujian tersebut untuk mengukur sejauh mana kriteria tersebut dipenuhi.

- Portability

Perangkat lunak dikatakan portable jika biaya untuk memindahkannya (transport dan adaptasi) ke lingkungan yang baru lebih kecil jika dibandingkan dengan biaya untuk membangun perangkat lunak tersebut dari awal.

- Reusability

Reusability adalah properti dari perangkat lunak yang memungkinkan perangkat lunak atau modul-modulnya digunakan kembali untuk sistem lain. Suatu perangkat lunak dikatakan reusable yang baik jika modul-modulnya dapat digunakan kembali untuk aplikasi lainnya.

- Interoperability

Interoperability adalah kemampuan suatu perangkat lunak untuk bekerja dengan perangkat lainnya tanpa mengalami kesulitan.

\section{B. Model Kualitas Alternatif}

1. Verifiability

Verifiability menggambarkan semudah apa memverifikasi performa dari suatu program. Beberapa sub faktor pada verifiability adalah [7]:

- Coding and documentation gueidelines

Berfokus untuk memberikan panduan dalam menuliskan kode dalam berbagai bahasa pemrograman dan petunjuk untuk mendokumentasikan suatu perangkat lunak dengan baik.

- Compliance (Complexity)

Berfokus untuk menjaga kompleksitas kode program yang dibangun sehingga tingkat verifikasinya tetap terjaga.

- Document Accessibility

Berfokus terhadap kemudahan untuk mengakses dokumentasi yang sudah disebutkan pada sub bab sebelumnya

- Traceability

Berfokus terhadap kemudahan untuk melakukan penelusuran suatu dokumentasi yang dimiliki oleh perangkat lunak tersebut. 
- Modularity

Berfokus kepada kefleksibelan suatu sistem. Mempunyai 5 kriteria, yaitu: protection decomposability, continuity, composability, understandability.

- Expandability

Expandability adalah kemampuan sebuah perangkat lunak untuk dikembangkan. Beberapa sub faktor dalam expandability antara lain [8]:

$\checkmark$ Extensibility: kemampuan sistem untuk dapat ditambahan suatu modul tanpa harus menimbulkan efek samping yang tidak diinginkan. Beberapa kriteria yang bisa digunakan untuk menilai tingkat

$\checkmark$ Modularity: kemandirian suatu fungsional dari suatu komponen program.

$\checkmark$ Generality: seberapa bisa perangkat lunak tersebut bisa menyelesaikan masalah pada domainnya.

$\checkmark$ Simplicity: tingkat dimana perangkat lunak dapat dimengerti tanpa kesulitan.

2. Safety

Safety dapat didefinisikan sebagai kemampuan untuk memperkecil resiko yang dapat membahayakan ke tingkat atau level yang dapat diterima. Selain itu safety adalah kemampuan untuk melakukan identifikasi, analisis, mempelajari, dan mengontrol software hazard atau fungsi berbahaya (data \& command) untuk memastikan melakukan operasi yang aman. Safety dapat dipecah menjadi bagian:

- Identifikasi: mencari dan menentukan hazard yang mungkin terjadi.

- Analisis: menganalisa hazard yang ditemukan untuk mengetahui resiko yang dapat terjadi.

- Mempelajari: mempelajari hasil analisa untuk mencari solusi yang dapat digunakan

- Mengontrol: mengontrol hazard yang telah ditemukan untuk meminimalisasi resiko yang mungkin terjadi

3. Manageability

Manageability dapat didefinisikan sebagai kemampuan untuk melakukan tindakan administrasi, melakukan pengawasan serta memperoleh informasi yang relevan dengan tindakan yang terkait. Beberapa kaitan manageability antara lain monitoring, tracking, dan control.

4. Survivability

Survivability adalah kehandalan sistem untuk memberikan layanan ketika terkena bencana yang dapat diukur dari lamanya waktu failure dan recovery [9].

\section{METODOLOGI PENELITIAN}

\section{A. Objek Penelitian}

Objek penelitian dilakukan di Politeknik Negeri Jakarta dengan layanan yang dinilai yaitu berupa Sistem Informasi Akademik (SIAK) PNJ. Jumlah responden yang dijadikan sampel sebanyak 49 orang mahasiswa dari berbagai jurusan di Politeknik Negeri Jakarta.

\section{B. Metode Penelitian}

a. Studi literatur terhadap faktor kualitas perangkat lunak

b. Pembuatan list faktor kualitas perangkat lunak

c. Penilaian kuliatas perangkat lunak

d. Pengolahan hasil pengisian dari hasil kuesioner terhadap kualitas perangkat lunak

e. Evaluasi terhadap hasil pengisian faktor kualitas perangkat lunak

\section{HASIL DAN PEMBAHASAN}

Penyusunan kuesioner yang digunakan menggunakan jawaban antara setuju dan tidak setuju terhadap pernyataan yang diberikan. Penyusunan kuesioner ditentukan dengan mengacu kepada faktor kualitas perangkat lunak dengan menggunakan metode McCall khususnya pada aspek Product Operation.

Pengolahan dan hasil pengujian kuesioner :

a. Correctness

\section{Terhadap Kelengkapan Fungsionalitas}

Pada faktor correctness berhubungan dengan kelengkapan dari fungsionalitas pada Sistem Informasi Akademik PNJ didapatkan bahwa website PNJ ini belum memenuhi beberapa fungsi fungsionalitas yang dibutuhkan oleh mahasiswa. Dari 49 mahasiswa menyatakan bahwa 37 mahasiswa merasa terdapat fiture yang tidak berjalan pada website PNJ dan ada 10 mahasiswa menyatakan bahwa fiture dari website PNJ telah memenuhi kebutuhan mahasiswa.

\section{Terhadap Kesesuaian Informasi}

Berdasarkan data yang diperoleh dari tanggapan mahasiswa terhadap kesesuaian informasi yang diberikan oleh website PNJ bahwa informasi yang ditampilkan oleh PNJ belum memenuhi kebutuhan 
mahasiswa. Dari 49 mahasiswa, terdapat 4 mahasiwa yang setuju bahwa Informasi akademik yang ditampilkan sudah sesuai dengan kebutuhan mahasiswa. 15 mahasiswa menyatakan bahwa informasi mengenai data kompensasi pada website PNJ telah sesuai. 7 mahasiwa yang menyatakan Informasi yang ditampilkan website PNJ selalu menampilkan berita terbaru atau up to date terhadap infromasi akademik PNJ.

b. Reliability

Melaksanakan fungsi

Berdasarkan data yang diperoleh dari tanggapan mahasiswa terhadap ketersedian fungsionalitas oleh website PNJ dinyatakan telah tercapai. Dari 49 mahasiswa, 16 mahasiswa menyatakan mengalami sulit $\log$ in ke website PNJ. Terdapat 16 mahasiswa menyatakan sering terjadinya hang atau error saat membuka website PNJ. 6 mahasiswa menyatakan bahwa setelah melakukan pengisian edom data yang dimasukkan tidak tersimpan. 16 mahasiwa menyatakan bahwa tingkat keamanan website PNJ cukup tinggi.

\section{Terhadap Kemampuan Download}

Berdasarkan hasil dari pengolahan kuesioner yang berhubungan dengan faktor reliability pada Sistem Informasi Akademik PNJ ini didapatkan bahwa kemampuan download sudah tercapai. Hal ini dapat dinyatakan dengan hasil kuesioner bahwa dari 49 mahasiswa terdapat 45 siswa yang menyatakan bahwa tidak terjadinya kegagalan saat melakukan pengunduhan bukti pengisian EDOM. Sementara hanya 5 mahasiswa yang mengalami kegagalan pengunduhan.

\section{c. Efficiency}

Berdasarkan hasil dari pengolahan kuesioner yang berhubungan dengan faktor efficiency pada Sistem Informasi Akadmeik PNJ ini dinyatakan belum tercapai. Berdasarkan 49 mahasiwa, 40 mahasiswa menyatakan kecepatan pemrosesan dalam pengaksesan website PNJ sedikit lama jika banyak mahasiswa yang sedang mengakses. 39 mahasiswa menyatakan server sering kali down disebabkan kurangnya ketersediaan penyimpanan pada server PNJ. 10 mahasiswa setuju dengan pernyataan adanya kapabilitas perantara komunikasi yang besar yang digunakan untuk mentransfer data.

\section{d. Integrity}

Berdasarkan hasil dari pengolahan kuesioner yang berhubungan dengan faktor integrity pada Sistem Informasi Akadmeik PNJ ini dinyatakan belum tercapai. Berdasarkan 49 mahasiwa, 22 mahasiswa menyatakan bahwa tingkat keamanan hak akses website PNJ sangat baik dan terdapat 14 mahasiswa menyatakan bahwa seluruh informasi yang bersangkutan dengan jurusan sudah terintegrasi secara menyeluruh.

e. Usability

Berdasarkan hasil dari pengolahan kuesioner yang berhubungan dengan faktor usability pada Sistem Informasi Akademik PNJ ini dinyatakan telah tercapai. Dari 49 mahasiwa, terdapat 38 mahasiswa yang menyatakan bahwa website PNJ mudah untuk digunakan oleh mahasiswa. 27 mahasiswa menyatakan bahwa adanya fiture bantuan (help) atau FAQ yang membantu pengunjung website yang kesulitan untuk menemukan informasi yang dinginkan. Setelah dilakukan pengolahan hasil dari kuesioner terhadap Sistem Informasi Akademik PNJ dapat disimpulkan data dalam bentuk Tabel 1 .

TABEL 1. PERSENTASE HASIL KUESIONER

\begin{tabular}{|c|c|c|}
\hline Faktor & Setuju & Tidak Setuju \\
\hline Correctness & $35.36 \%$ & $64.64 \%$ \\
\hline Reliability & $68.38 \%$ & $31.62 \%$ \\
\hline Efficiency & $31.2 \%$ & $68.8 \%$ \\
\hline Integrity & $36.75 \%$ & $63.25 \%$ \\
\hline Usability & $65.3 \%$ & $34.7 \%$ \\
\hline
\end{tabular}

Pada faktor correctnes hanya terdapat $35.36 \%$ mahasiswa yang setuju dengan hasil kuesioner yang menandakan bahwa faktor correctness belum tercapai. Faktor reliability memiliki persentase bahwa mahasiswa yang setuju sebesar $68.38 \%$ yang menandakan faktor ini telah tercapai. Pada faktor efficiency mahasiswa yang setuju sebesar $31.2 \%$ yang menandakan faktor ini belum tercapai. Pada faktor integrity hanya terdapat $36.75 \%$ mahasiswa yang setuju dengan hasil kuesioner yang menandakan bahwa faktor ini belum tercapai. Faktor usability memiliki persentase mahasiswa yang setuju sebesar $65.3 \%$ yang menandakan faktor ini telah tercapai.

\section{KESIMPULAN DAN SARAN}

\section{A. Kesimpulan}

Berdasarkan data yang diperoleh dari tanggapan mahasiswa terhadap Sistem Informasi Akademik Politeknik Negeri Jakarta dengan model McCall, didapat bahwa masih terdapat kekurangan berdasarkan faktor correctness, efficiency, dan integrity. Beberapa kekurangan tersebut terdapat pada kemampuan aplikasi dalam menampilkan informasi kepada mahasiswa yang masih belum sesuai. Selain itu juga terletak pada penanganan kegagalan perangkat lunak tersebut. Namun penggunaan aplikasi ini sudah dapat memenuhi kebutuhan pengguna apabila dilihat dari faktor usability dan reliability. 


\section{B. Saran}

Setelah melakukan penelitian ini diberikan saran-saran sebagai berikut:

1. Sebaiknya menampilkan informasi akademik yang selalu up-to-date dengan akurat dan lengkap.

2. Memberikan fungsi yang dapat membantu proses perkuliahan untuk mahasiswa.

3. Membuat user interface yang mudah dimengerti oleh mahasiswa.

4. Fiture yang telah tersedia pada website PNJ sebaiknya dapat berjalan dengan baik dan mengurangi dan error/ hang yang terjadi.

5. Data SIAK PNJ seharusnya terintegrasi dengan setiap jurusan yang ada di PNJ.

\section{REFERENSI}

[1] Basu, Anirban. 2015. Software Quality Assurance, Testing and Metrics. Delhi : PHI Learning Private

[2] Hapsari, Rinci Kembang dan M Jauhari Husen WP. 2015. Estimasi Kualitas Perangkat Lunak Berdasarkan Pengukuran Kompleksitas Menggunakan Metrik Finction Oriented. Seminar Nasional Sains dan Teknologi Terapan. ISBN 978-602-98569-1-0. Surabaya. http://jurnal.itats.ac.id/wp-content/uploads/2015/10/19.

Rinci-Kembang_edited.pdf, 10 Mei 2017

[3] Hilabi, Shofa Shofiah. 2015. Analisis Kualitas Perangat Lunak Terhadap Sistem Informasi STT Wastukancana Purwakarta. ISSN 1693-2978. https://sttwastukancana.ac.id/jurnal/.../5.-ARTIKEL-SQA-SHOFA-15finish.pdf, 17 Mei 2017.
[4] Bachtiar, Adam Mukharil. Dian Dharmayanti dan Mira Kania Sabariah. Oktober 2013. Analisis Kualitas Perangkat Lunak Terhadap Sistem Informasi UNIKOM. Majalah Ilmiah UNIKOM. Vol.11, No.02, http://kepo.unikom.ac.id/30392/1/07-miu-11-2-adam-cs.pdf, 10 Mei 2017.

[5] Mulyanto, Agus. Mei 2016. Pengujian Sistem Informasi Akademik Menggunakan McCall's Software Quality Framework, 17 Juli 2017.

[6] Sugiantoro, Bambang dan M. Mustakim. Juni 2017. Analisa Usabilitas Sistem Deteksi Akses Pornografi Pengguna Internet Menggunakan Metode Mccall'S. Volume 2 No. 1. http://join.if.uinsgd.ac.id/index.php/join/article/viewFile/10/6 0-pdf, 17 Juli 2017.

[7] Miguel, Jose P. David Mauricio dan Glen Rodriguez. November 2014. A Review od Software Quality Models for The Evalution of Software Products. International Journal of Software Engineering \& Applications. Vol.5, No.06, http://airccse.org/journal/ijsea/papers/5614ijsea03.pdf, 14 Mei 2017.

[8] Swari, Ni Made Satvika. Juni 2015. Review Perangkat Lunak StarUML Berdasarkan Faktor Kualitas McCall. Vol.VII, No.1

http://library.umn.ac.id/jurnal/public/uploads/papers/pdf/a708 a8a49a087aa1e7dcd4bb1ec158a4.pdf, 10 Mei 2017.

[9] Winkler, Dietmar. Stefan Biffl dan Johannes Bergsmann. 2014. Software Quality. Model-Based Approaches for Advanced Software and ystems Engineering. Switzerland: Springer International Publishing Switzerland. 